\title{
Evaluating Rainfall Risk Profile of Indian Subcontinent Based on Index Metrics
}

\author{
Bharath V $P h D$ \\ Research Scholar \\ DoS in Commerce \\ University of Mysore, Mysuru, Karnataka, India \\ E-mail: bharathv@commerce.uni-mysore.ac.in \\ Kotreshwar G $P h D$ \\ Professor (Rtd.) \\ Senior Fellow, ICSSR, New Delhi, India \\ E-mail: kotreshwar@commerce.uni-mysore.ac.in
}

Received: July 09, 2020

doi: I0.4628I/ijfb.v4i2.700
Accepted: July 20, 2020

Online Published: August 09, 2020

URL: https://doi.org/I0.4628I/ijfb.v4i2.700

\begin{abstract}
Floods and droughts represent an embedded monsoon factor impacting the Indian economy. Evaluating monsoon risk based on rainfall index metrics could help design appropriate alternative risk transfer products. This study proposes a new set of rainfall indices that can be used to explore the excess rainfall risk profile of the Indian Subcontinent. The study proposed a new set of indices for evaluating excess rainfall risk profiles which are defined as Excess Rainfall Days (ERDs). The methodology proceeds in a step-wise form: Empirical values of ERDs over 50 years for selected MSDs of India are derived, and then these index values are analyzed for determining the degree of variability and volatility, followed by the examination of the degree of inter-correlation amongst indices of selected Meteorological Sub-divisions. The research is based on the applications of econometric models such as the Augmented Dickey-Fuller (ADF) test followed by the GARCH model. The results revealed that several of the statistical properties of ERD indices support the idea that these indices could be used as building blocks for designing rainfall derivatives similar to HDDs/CDDs underlying temperature derivatives.
\end{abstract}

Keywords: Rainfall Indexation, Floods, Excess Rainfall Days (Erds), Rainfall Derivatives.

JEL Classification Codes: F37, GI9, G29, G22, Q59.

\section{Introduction}

India is exposed to a wide range of weather-related risks such as droughts, floods, storms, landslides, and extreme temperatures. India's economic losses from weather-related events have doubled over the last thirty years (Singh, Del Rio, Soundarajan, Nath, \& Shivaranjani, 2018). A report of McKinsey Global Institute has found that economic damage incurred by Mumbai (India) from flash floods could be almost double by 2050. Therefore, Floods are the most economically damaging weather-related events, costing more than all other disaster events combined. From 1998 to 2017 , I0 out of I4 extreme weather-related disasters were floods, causing economic damage of approximately US $\$ 45$ billion and killing over 27000 people and affecting more than 370 million people (Singh et al., 2018) in India. Therefore, Effective management of excess rainfall risk is essential for achieving sustainable development of the economy. Traditional risk management tools like crop insurance programs are found to be grossly inadequate. A recent innovation in the financial markets involves the development of a rainfall-index based on derivative products as a risk management tool to hedge excess rainfall. Rainfall derivatives (RDs) represent new alternative risk transfer tools that could be used in the capital market to minimize the adverse impact of floods on the Indian economy. India has well-developed financial markets and it has been experiencing hassle-free trading from the past two decades. Even the Securities and Exchange Board of India (SEBI) has actively been considering a proposal to allow trading in weather derivatives. Therefore, India too needs such derivative products, as investors are more mature now, this product would be a game-changer for many stakeholders. This study introduces a new set of rainfall indices that can be used as building blocks for designing rainfall derivatives contracts.

The proposed study aims to determine rainfall indices for selected Meteorological Sub-divisions (MSDs) of India based on a new methodology. The Statistical properties of computed indices will be analyzed to assess the rainfall risk profile. The study also intends to examine the relationship of rainfall Indices among the selected Meteorological Subdivisions of India. 


\section{Floods in India}

Most of the losses faced by India are due to an increase in flood events and cyclones, which are projected to increase in magnitude and frequency in the near future. Hence, India has high exposure to weather-related events. In 2018, a prolonged southwest monsoon over the state of Kerala resulted in one of the worst floods in IOO years, causing estimated losses of US $\$ 4.25$ billion. Over 8 lakh people were displaced and 400 lives lost over a span of 2 weeks (Chacko, Ranadive, Sachdeva, Hede, Bhati, Nainan, \& Jagasheth, 2018). In 2019, many states across the country have witnessed severe drought conditions, followed by a delayed monsoon, which was made up for by spells of high-intensity rainfall resulting in heavy flooding across the country. Therefore, Indian summer monsoon volatility could adversely impact agriculture, water resources, power generation, and the overall economy (Mooley, Parthasarathy, Sontakke, \& Munot, I98I; Mooley \& Parthasarathy, 1983; Parthasarathy, Munot, \& Kothawale, 1994). Kumar and Parikh (200I) found that there was a strong relationship between agricultural performance and climate; and there will be a significant loss in net revenue due to global warming. However, drought impacts less frequently in some areas of India, floods cause severe damage to livelihood and agriculture in other areas; one-third of the average flood-prone area in the country constitutes agricultural land (IPCC, 1995).

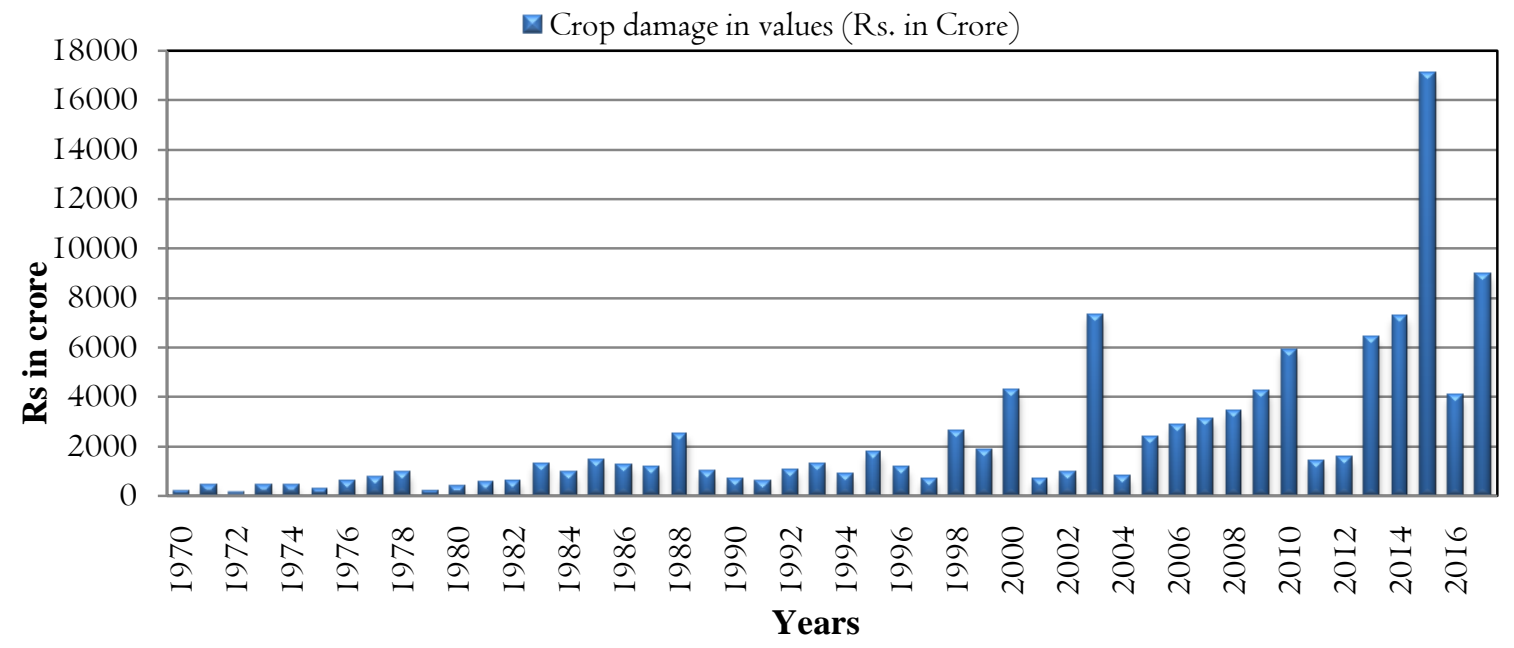

Figure I. Total crops damages due to floods in India from 1970-2017

Source: Flood Damage Statistics Report, Central Water Commission, Government of India (2019)

Figure I shows the year-wise total crop damage due to floods from 1970 to 2017. From 1970 to 2017, India suffered damages due to floods and heavy rains. The year 2015 was the most catastrophic for India. The data from the Central Water Commission show the country's total crop loss due to floods in 2015 was Rs. 17043.98 Crore. Moreover, crop damage due to floods and heavy rainfall has increased exponentially in the last two decades (Figure I).

India is among the countries most affected by weather-related risk. Most of the studies have found that floods will become more frequent in India. CWC report shows the year-wise area affected due to floods. It shows that the area affected by floods in India does not follow any pattern. The lowest area affected by floods in India was I.09 million hectares in 2006 and the highest was in 1978 with an area of 17.5 million hectares. The most recent and devastating example was 2013 in Kedarnath, 2015 in Chennai, 2018 in Kerala, 2019 in Karnataka and Maharashtra. According to the Central Water Commission report on state-wise flood damage statistics show that West Bengal was the highest damage to crop due to floods and heavy rain followed by Andhra Pradesh, Karnataka, Uttarakhand, Uttara Pradesh, Kerala, and Arunachal Pradesh.

\section{Rainfall Derivatives}

Developments in global financial markets provide unique opportunities for managing catastrophic risks. The two promising innovations that could provide for effective management of monsoon risk are (I) Index-based insurance contracts and (2) Rainfall derivatives. Index-based insurance is an alternative form of insurance that makes payments based not on measures of farm yields, but rather on some objective weather event such as rainfall. Agricultural insurance is an industry that is still in its evolution stages in India. Rainfall index (RI) insurance introduced by leading insurance companies in India in the recent past holds better prospects over traditional crop insurance. The development of RI insurance just marks the beginning of a journey towards the creation of full-fledged rainfall markets for absorbing monsoon risk to meet the hedging needs of a wide range of stakeholders including agri-insurers, agri-finance companies, commodity trading enterprises, hydropower utilities, agro-processing companies, etc. Designing such a derivative requires determination of rainfall index metrics 
which could be used as building blocks. In 20I I Chicago Mercantile Exchange (CME) pioneered trading rainfall futures and options on monthly and seasonal rainfall indices.

\section{Research Questions}

- What should be the framework for the standardization of measures of rainfall indices for quantifying excess rainfall risk?

- What should be the approach for deriving empirical values of excess rainfall indices of Meteorological Subdivisions of India?

- What are the statistical properties of the empirical values of excess rainfall indices?

\section{Research Methodology}

The following methodology is adapted to analyze the rainfall time series data. The research is based on the applications of econometric models such as the Augmented Dickey-Fuller(ADF) test followed by the GARCH model.

\section{I Study Area}

The high intensive monsoon rain and melting of Himalayan glaciers is a major source of flood in India. According to Central Water Commission (CWC) report on state-wise flood damage statistics show that West Bengal has the highest damage to crop due to floods and heavy rain followed by Andhra Pradesh, Karnataka, Uttrakhand, Uttar Pradesh, Kerala, Arunachal Pradesh, Gujarat region and Saurashtra region. The sample consists of the top I0 floods damaged Meteorological Sub-division of India based on the Central Water Commission Report.

\subsection{Data and Methodology}

A standard methodology for rainfall indexation is yet to emerge. Stoppa and Hess (2003) developed a rainfall index on several aggregated weights of average rainfall in ten-day periods in each growth stage. National Commodity Derivative Exchange (NCDEX) proposed a rainfall index based on historical cumulative rainfall. First Rainfall Index for Mumbai city was launched in 2005. Rainfall Index (RI) for a stated location is determined as:

$$
\mathrm{RI}_{\text {location }}=\frac{\sum r_{i t}}{\sum R_{i t}} X \text { scale value }
$$

Where $\mathrm{r}_{\text {it }}$ represents actual rainfall of $\mathrm{i}^{\text {th }}$ day of the $\mathrm{t}^{\text {th }}$ season; $\mathrm{R}_{\mathrm{t}}$ represents long period average daily rainfall of $\mathrm{i}^{\text {th }}$ day of the $\mathrm{t}^{\text {th }}$ season; scale or multiplier value was assumed $\mathrm{IOOO}$ (rainfall is measured equivalent to $\mathrm{I} / 1000^{\text {th }}$ of a met, i.e., in millimeter). RI location indicates what percentage of cumulative normal expected rainfall is realized, which means a higher the rainfall index value meaning that compared to the cumulative average rainfall up to the date of an index, there has been more rainfall.

Similarly, in 2005, Multi Commodity Exchange (MCX) and Weather Risk Management Services Pvt. Ltd. jointly developed rainfall indices based on historical annual cumulative rainfall and it adjusted with excess and deficit of actual cumulative rainfall as of that data. The adjustment factor takes into account the impact of historical and actual rainfall during the period.

Kotreshwar (2006), Kotreshwar \& Kanakasabai, (2006), Kotreshwar \& Arunkumar (2006), Shivkumar \& Kotreshwar (2013), Kotreshwar (2015) proposed process of rainfall indices based on a ticker value defined as Monsoon Outcome Index (MOX) and estimated their statistical properties of MOX series across time and subdivisions, and the study examined the potential of MOX as a new asset class for inclusion in the portfolio for risk hedging.

Later, Kotreshwar (2015) has modified their suggested methodology to compute rainfall indices as Deficit Rainfall Days (DRDs) and Excess Rainfall Days (ERDs). This approach appears to be more relevant to define and evaluate rainfall variability using DRD/ERD measures as standard metrics. The present study is based on this new approach for rainfall indexation.

Two important characteristics within the rainfall time series are highly skewed and volatility clustering. A series with some periods of low volatility and some periods of high volatility is said to exhibit volatility clustering. Volatility clustering can be thought of as clustering of the variance of the error term over time that is if the regression error has a small variance in one period; its variance tends to be small in the next period, too. In other words, volatility clustering implies that the error exhibits time-varying heteroscedasticity, that is, unconditional standard deviations are not constant. These characteristics can be captured by the GARCH family models.

The residuals can be modeled with ARCH dynamics. The conditional variance allows for two types of volatility dynamics that are relevant in rainfall. They include seasonal volatility and autoregression effects in which shocks to the conditional variance may have effects that persist for several periods. Campbell and Diebold (2005) use an autoregressive moving average (ARMA) time series model for temperature and observe seasonality in the autocorrelation function for the (squared) residuals when modeling the temperature in US cities. They propose a seasonal autoregressive conditional heteroskedastic $(\mathrm{ARCH})$ process to model volatility. A similar method adopted by Anastasiadou and López-Cabrera (2013) proposed a GARCH model to identify volatility in weather indices. 


\subsection{Methodology}

Excess rainfall at a given location needs to be quantified using a standard metric. For this purpose, the historical daily average rainfall for the selected location would serve as the 'base' rainfall for calculating the metric. Rainfall at a location equivalent to being above a defined normal rainfall by one millimeter for one day can be denoted 'Excess Rainfall Day' (ERD). For example, given the historical daily average rainfall for June for a location is $3 \mathrm{~mm}$ and if the actual daily average rainfall is $5 \mathrm{~mm}$, we can approximate the ERD for June as 60 ( $2 \times 30$ days). A South-West monsoon season of 4 months (June-Sept) might accumulate a seasonal minimum of zero or a maximum of over I00 ERD for a location. A zero ERD means that all the four months recorded deficit rainfall.

The underlying variable being rainfall, let $\mathrm{R}_{i}$ denote the rainfall (in millimeters) measured on $\mathrm{i}^{\text {th }}$ day, and $\mathrm{R}_{x}$ denotes the average daily rainfall (in millimeters). The average daily rainfall, $R_{x}$, should serve as the reference level of rainfall in millimeters. The value of $R_{x}$ is based on the past rainfall data for any chosen length of the period. The standard underlying variable, then, would be simply the difference between the daily average value of rainfall (in millimeters), i.e., $\mathrm{R}_{x}$ and the actual value of rainfall (in millimeters) on $\mathrm{i}^{\text {th }}$ day, i.e., $\mathrm{R}_{\mathrm{i}}$. The ERD generated on a given $\mathrm{i}^{\text {th }}$ day then is given by:

$E R D_{i}=M_{a x} .\left\{R_{i}-R_{x}, 0\right\}$

In equation (2) above, it can be seen that the number of ERD for a specific day is just the number of millimeters that the rainfall deviates from a reference level. The methodology adopted in this paper comprises the following steps:

- Estimation of reference level of rainfall for each of the selected meteorological sub-divisions(MSDs) of India

- Estimating the ERD for each month of the south-west monsoon

- Taking the sum of ERD for all the four months

The number of accumulated ERD $\left(E_{n}\right)$ for a period of ' $n$ ' days can be determined as follows:

$$
E_{n}=\sum_{i=1}^{n} E R D_{i}
$$

Monthly ERD facilitates to capture the element of variability in each month of the south-west monsoon. The values of ERD based on equations (2) \& (3) for the selected I0 of the 36 MSDs of India are determined for each of the 50 years from 1970-2019 (Appendix-I). The sample data is drawn from the official website of the Indian Meteorological Department (IMD) of India.

The study is based on secondary data. The rainfall data is collected from the India Meteorological Department (IMD). The study covered monthly average rainfall data of the south-west monsoon season (June to September) for the analysis. The study covers the past 50 years (I970 to 2019) rainfall data of selected I0 of the 36 Meteorological subdivisions of India is considered.

\subsection{Statistical Tests}

The homogeneity test is to test whether a given data is said to be homogenous over time. In other words, if there is a significant break in the trend of particular time series it is classified as inhomogeneous. This inhomogeneity in historical data will impact the outcome of data analysis and forecasts. Hence, it is important to test the homogeneity of the rainfall data series by applying four methods Pettitt, SNHT test, Buishand, and Von Neumann test.

Most of the statistical procedures including correlation, regression, and analysis of variance are parametric tests. These parametric tests are based on the assumption that the data follows a normal distribution. To test the normality of the data series Shapiro-Wilk test and Jarque-Bera test have been applied. The null hypothesis is that sample distribution is normal. If the computed $\mathrm{p}$-value is lower than the significance level alpha $=0.05$, it is indicated that the data series is not normally distributed.

Augmented Dickey-Fuller (ADF) test suggested by Dickey and Fuller (1979, 198I) is applied for the null hypothesis that a series $\left(Y_{t}\right)$ is non-stationarity by calculating at-statistics for $\beta=0$ in the following equation:

$$
\Delta Y_{t}=\alpha_{1}+\beta Y_{t-1}+\gamma_{t}+\sum_{t-1}^{n} \delta_{k} \Delta Y_{t-k}+\varepsilon_{t}
$$

Where $\mathrm{k}=2,3, \ldots . . \mathrm{n}$. while, $\alpha, \beta, \gamma$, and $\delta$ are the parameters to be estimated and $\boldsymbol{\varepsilon}_{\boldsymbol{t}}$ is a white noise error term. If the value of the $\mathrm{ADF}$ statistic is less than the critical value at the conventional significance level (usually at $5 \%$ significance level) then the series $\left(Y_{t}\right)$ is said to be stationary and vice versa. If $\left(Y_{t}\right)$ is found to be non-stationary then it should be determined whether $\left(Y_{t}\right)$ is stationary at first differences $\Delta Y_{t}-I(0)$ by repeating the above procedure. The first difference of the series is stationary then the series $\left(Y_{t}\right)$ may be concluded as integrated of order one i.e. $Y_{t}-I(0)$.

To analyze the existence of autocorrelation, if any, the following autocorrelation function (ACF) for rainfall time series $r_{t}$ is applied:

$$
\operatorname{Corr}\left(r_{t}, r_{t-k}\right), k=1,2 \ldots . . n
$$

Where the value of $\mathrm{k}$ is the time gap is considered. A lag $\mathrm{I}$ autocorrelation (i.e,,, $\mathrm{k}=\mathrm{I}$ in the above) is the correlation between values that are one time period apart. The ACF is a way to measure the linear relationship between an 
observation at time $t$ and the observations at previous times. If the coefficient of correlation falls between the upper and lower limits of a confidence interval, then the data is considered auto correlated.

To analyze the variability of rainfall amongst meteorological subdivisions, the GARCH model has been applied. Under GARCH (Bollerslev, 1986) model the forecasts of time-varying variance depend on the lagged variance of any asset. This GARCH $(\mathrm{I}, \mathrm{I})$ can be expressed as;

$$
\sigma_{t}^{2}=k+\sum_{i=1}^{p} \alpha \epsilon_{t-1}^{2}+\sum_{j=1}^{q} \beta \sigma_{t-1}^{2}+\epsilon_{t}
$$

Where the conditional volatility $\left(\sigma_{t}^{2}\right)$ is specified in the above model is determined by three effects namely, $\mathrm{k}$ is a constant term, $\alpha \in_{t-1}^{2}$ indicates yesterday's news about volatility illustrated by the ARCH term, and $\beta \sigma_{t-1}^{2}$ explains the forecasted volatility from the previous period called as GARCH component, $\epsilon_{t}$ is the error term. $\mathrm{P}$ is the degree of ARCH term and $\mathrm{Q}$ is the degree of GARCH term. The parameters $\alpha$ and $\beta$ define as short-run dynamics of the resulting volatility time series. The coefficient is close to the one we assume that there is a high persistence of volatility.

\section{Results and Discussion}

The preliminary analysis for this study included computing statistical parameters like mean, median, maximum, minimum, standard deviation, skewness, and kurtosis for Excess Rainfall Days (ERD) in the South-west rainfall series of selected Meteorological sub-divisions for 50 years the period from 1970 to 2019 as shown in Table-I.

Table I. Summary of descriptive statistics of ERD values of selected MSDs in India

\begin{tabular}{|c|c|c|c|c|c|c|c|c|}
\hline Regions & Sub-divisions & Mean & Median & Maximum & Minimum & $\mathrm{SD}$ & Skewness & Kurtosis \\
\hline \multirow[t]{3}{*}{ North } & HIMACHAL PRADI & II0.86 & I06.03 & 472.90 & 0.00 & 107.90 & 1.02 & 4.12 \\
\hline & UTTARANCHAL & 156.70 & 138.50 & 673.00 & 0.00 & $\mathrm{I53.24}$ & 1.32 & 4.56 \\
\hline & WEST UP & $\mathrm{I} 22.5 \mathrm{I}$ & I3I.00 & 443.88 & 0.00 & I04.46 & $0.7 \mathrm{I}$ & 3.44 \\
\hline \multirow[t]{2}{*}{ South } & COSTAL AP & 81.65 & 75.58 & 272.8 & 0.00 & 75.02 & 0.79 & 2.76 \\
\hline & $\begin{array}{l}\text { SOUTH INTERIOR } \\
\text { KAR }\end{array}$ & 85.59 & 78.08 & 239.57 & 0.00 & $68.4 \mathrm{I}$ & 0.42 & 2.14 \\
\hline \multirow[t]{3}{*}{ East } & BIHAR & I38.07 & 153 & 553.7 & 0.00 & III.58 & I.19 & 5.34 \\
\hline & GANGETIC WB & 152.82 & I4I.38 & 465.88 & 0.00 & $\mathrm{I} 27.85$ & 0.59 & $2.4 \mathrm{I}$ \\
\hline & ODISHA & 124.04 & 99.00 & 483.00 & 0.00 & I2I.02 & 1.39 & 4.55 \\
\hline \multirow[t]{2}{*}{ West } & GUJRAT & I98.5I & 159.00 & 663.52 & 0.00 & I7I.42 & $0.9 \mathrm{I}$ & 3.19 \\
\hline & SAURASHTRA & I6I.94 & 104.54 & II73.47 & 0.00 & 197.89 & 2.94 & $\mathrm{I} 4.86$ \\
\hline
\end{tabular}

Source: E-views output of the data sourced from IMD reports -I970 to 2019

The mean of Excess Rainfall Days (ERDs) values is highest in the west region followed by East and North. The highest and lowest mean values are 198.5I and 81.65 for Gujarat and Coastal Andhra Pradesh respectively. It is observed that mean values in the ERD are different in all subdivisions. The maximum ERD value is in the West region followed by the North and East regions. Saurashtra region (I 173.47) has the highest ERD values and the lowest is in South Interior Karnataka (239.57). The standard deviation method is used to measure the volatility in the ERD values. West region has the highest volatility in the ERD values followed by the east and north region. Moreover, the South region has the lowest standard deviation values. Saurashtra (197.89) has the highest volatility among the selected MSDs while south interior Karnataka(68.I) has the lowest.

The rainfall derivatives contracts payoff is based on an underlying index (ERD) which is observed from rainfall data at a specific geographic location. Based on this, the mean ERDs values for the selected regions would serve as the 'base' for calculating the payoff of the contract. For example, from the above table-I, the mean ERDs values of south-west monsoon season for Gujarat were $198.5 \mathrm{I} \mathrm{mm}$, this value indicates that every year Gujarat has been facing a minimum of I $93.84 \mathrm{~mm}$ of excess rainfall from the south-west monsoon season. These ERDs values of the Gujarat region would serve a benchmark for designing rainfall options and futures contracts for trading in the markets.

Skewness is a measure of the abnormality of the distribution of the data series around its mean. All sub-divisions were positively skewed, which means the distribution has a long right tail. Kurtosis measures the flatness or peakedness of the data series. Out of 10 sub-divisions, the Kurtosis value of 3 sub-divisions was less than 3 , indicating that the distribution is flat (platykurtic) relative to the normal. Seven sub-divisions have a kurtosis value of more than 3 ; the distribution is peaked (leptokurtic) relative to the normal. 
Table 2. Summary of Homogeneity test

\begin{tabular}{|c|c|c|c|c|c|}
\hline Regions & Sub-divisions & Pettitt & $\begin{array}{r}\text { SNHT } \\
\text { test } \\
\end{array}$ & Buishand & $\begin{array}{c}\text { von } \\
\text { Neumann }\end{array}$ \\
\hline \multirow[t]{3}{*}{ North } & $\begin{array}{l}\text { HIMACHAL } \\
\text { PRADESH }\end{array}$ & 0.258 & $0.43 \mathrm{I}$ & 0.230 & 0.239 \\
\hline & UTTARANCHAL & & & & \\
\hline & WEST UP & 0.082 & O.I II & 0.046 & 0.874 \\
\hline \multirow[t]{2}{*}{ South } & $\begin{array}{l}\text { COSTAL ANDHRA } \\
\text { PRADESH }\end{array}$ & 0.892 & $0.64 \mathrm{I}$ & 0.364 & 0.916 \\
\hline & $\begin{array}{l}\text { SOUTH INTERIOR } \\
\text { KARNATAKA }\end{array}$ & 0.222 & 0.391 & 0.896 & 0.675 \\
\hline \multirow[t]{3}{*}{ East } & BIHAR & 0.359 & 0.330 & 0.291 & 0.276 \\
\hline & $\begin{array}{l}\text { GANGETIC WEST } \\
\text { BENGAL }\end{array}$ & 0.406 & 0.453 & $0.34 \mathrm{I}$ & 0.339 \\
\hline & ODISHA & 0.838 & $0.49 \mathrm{I}$ & 0.258 & 0.297 \\
\hline \multirow[t]{2}{*}{ West } & GUJRAT REGION & 0.328 & 0.521 & 0.726 & 0.057 \\
\hline & SAURASHTRA & 0.066 & 0.019 & 0.073 & 0.034 \\
\hline
\end{tabular}

Note: Tested at $5 \%$ significance level.

Source: E-views output of the data sourced from IMD reports -I970 to 2019

The results of the homogeneity test of ERD values have been tested using Pettitt, SNHT test, Buishand, and von Neumann test. If an ERD series may be considered as homogeneous over time, or if there are some years at which a change occurs. The null hypothesis is that a time series is homogenous between two given times. The above results indicating that all the MSDs follow homogeneously. As the computed $\mathrm{p}$-value is greater than the significance level alpha $=0.05$, one cannot reject the null hypothesis. Therefore, the ERD values considered as homogenous over time.

Table 3. Result of the stationary test from Augmented Dickey-fuller test (ADF) test

\begin{tabular}{|c|c|c|c|c|c|}
\hline Regions & Sub-divisions & Level Data & $\begin{array}{l}\text { Ist } \\
\text { Difference }\end{array}$ & Order & Decision \\
\hline \multirow[t]{3}{*}{ North } & HIMACHAL PRADESH & 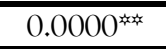 & - & $\mathrm{I}(0)$ & Stationary at level \\
\hline & UTTARANCHAL & $0.14 \mathrm{I} 2$ & 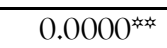 & $\mathrm{I}(\mathrm{I})$ & Stationary at difference \\
\hline & WEST UP & 0.3433 & 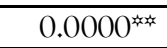 & $\mathrm{I}(\mathrm{I})$ & Stationary at difference \\
\hline \multirow[t]{2}{*}{ South } & $\begin{array}{l}\text { COSTAL ANDHRA } \\
\text { PRADESH }\end{array}$ & $0.0052^{\text {柿 }}$ & - & $\mathrm{I}(0)$ & Stationary at level \\
\hline & $\begin{array}{l}\text { SOUTH INTERIOR } \\
\text { KARNATAKA }\end{array}$ & 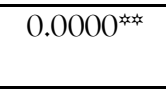 & - & $\mathrm{I}(0)$ & Stationary at level \\
\hline \multirow[t]{3}{*}{ East } & BIHAR & $0.0000^{\text {米惊 }}$ & - & $\mathrm{I}(0)$ & Stationary at level \\
\hline & $\begin{array}{l}\text { GANGETIC WEST } \\
\text { BENGAL }\end{array}$ & $0.0000^{\text {到 }}$ & - & $\mathrm{I}(0)$ & Stationary at level \\
\hline & ODISHA & 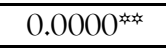 & - & $\mathrm{I}(0)$ & Stationary at level \\
\hline \multirow[t]{2}{*}{ West } & GUJRAT REGION & $0.0000^{\text {社 }}$ & - & $\mathrm{I}(0)$ & Stationary at level \\
\hline & SAURASHTRA & $0.0003^{\text {柿 }}$ & - & $\mathrm{I}(0)$ & Stationary at level \\
\hline
\end{tabular}

Table 3 shows the stationary test of selected metrological sub-divisions of India. Rainfall series is said to be stationary if the mean and variance of the series do not change over time, significance that stationery can be defined as no trend, constant variance over time, and no seasonality in the data series. To identify the stationarity in the rainfall series, Augmented-Dickey Fuller (ADF) test has been applied. The results display that South, West, and East regions are stationary at level data, only North sub-divisions are stationary at first difference. South, West, and East region series are stationary, indicating that these regions ERD values have no trend and no seasonality in the series. North region is nonstationarity at level data, indicating that North region ERD values have long-term trend and seasonality (fluctuations) in series. 
Table 4. Results of Normality Test

\begin{tabular}{|c|c|c|c|}
\hline Regions & Sub-divisions & Shapiro-Wilk & Jarque-Bera \\
\hline \multirow[t]{3}{*}{ North } & HIMACHAL PRADESH & 0.000 & 0.003 \\
\hline & UTTARACHAL & $<0.000 \mathrm{I}$ & $<0.000 \mathrm{I}$ \\
\hline & WEST UP & $0.00 \mathrm{I}$ & 0.095 \\
\hline \multirow[t]{2}{*}{ South } & $\begin{array}{l}\text { COSTAL ANDHRA } \\
\text { PRADESH }\end{array}$ & $0.00 I$ & 0.069 \\
\hline & $\begin{array}{l}\text { SOUTH INTERIOR } \\
\text { KARNATAKA }\end{array}$ & 0.006 & 0.216 \\
\hline \multirow[t]{3}{*}{ East } & BIHAR & 0.001 & $<0.0001$ \\
\hline & $\begin{array}{l}\text { GANGETIC WEST } \\
\text { BENGAL }\end{array}$ & 0.004 & 0.162 \\
\hline & ODISHA & $<0.000 \mathrm{I}$ & $<0.000 \mathrm{I}$ \\
\hline \multirow[t]{2}{*}{ West } & GUJRAT REGION & 0.001 & 0.029 \\
\hline & SAURASHTRA & $<0.000 \mathrm{I}$ & $<0.000 \mathrm{I}$ \\
\hline
\end{tabular}

Note: Tested at 5\% significance level.

Source: SPSS output of the data sourced from IMD reports -1970 to 2019

Several statistical methods can be used to identify the normal distribution. The results of the normality of ERD values have been tested using Shapiro-Wilk and Jarque-Bera test. Table4 shows that all the MSDs do not follow a normal distribution. As the computed $p$-value is lower than the significance level alpha $=0.05$, it is observed that the ERD values of selected sub-divisions are not normally distributed, and hence, the non-parametric test can be used for further analysis.

Table 5. Results of Autocorrelation Function (ACF) of selected MSDs of India

\begin{tabular}{|c|c|c|c|c|c|c|c|c|c|c|}
\hline & \multicolumn{3}{|c|}{ North } & \multicolumn{2}{|c|}{ South } & \multicolumn{3}{|c|}{ East } & \multicolumn{2}{|c|}{ West } \\
\hline $\begin{array}{l}\text { Lags } \\
\text { (k) }\end{array}$ & $\begin{array}{l}\text { Himachal } \\
\text { Pradesh }\end{array}$ & $\begin{array}{l}\text { Uttaranch } \\
\text { al }\end{array}$ & West UP & $\begin{array}{l}\text { Costal } \\
\text { AP }\end{array}$ & SIK & Bihar & $\begin{array}{l}\text { Gangetic } \\
\mathrm{WB}\end{array}$ & Odisha & Gujrat & $\begin{array}{l}\text { Saurasht } \\
\text { ra }\end{array}$ \\
\hline I. & 0.095 & $-0.49 \mathrm{I}$ & -0.635 & -0.193 & -0.120 & 0.064 & 0.039 & 0.066 & 0.187 & $-0.0 \mathrm{II}$ \\
\hline 2. & $0.15 \mathrm{I}$ & $-0.16 \mathrm{I}$ & 0.106 & 0.001 & 0.020 & 0.013 & -0.132 & 0.057 & -0.024 & 0.065 \\
\hline 3. & -0.001 & 0.406 & 0.237 & 0.046 & $-0.14 \mathrm{I}$ & 0.230 & -0.109 & -0.046 & 0.053 & -0.032 \\
\hline 4. & -0.116 & -0.318 & -0.473 & -0.377 & -0.120 & -0.004 & -0.006 & $-0.13 \mathrm{I}$ & -0.067 & 0.028 \\
\hline 5. & 0.020 & 0.024 & 0.494 & 0.242 & -0.007 & -0.155 & -0.205 & 0.094 & -0.217 & -0.115 \\
\hline 6. & -0.039 & 0.034 & -0.339 & -0.218 & 0.135 & -0.004 & 0.149 & -0.080 & -0.080 & 0.046 \\
\hline 7. & 0.161 & 0.084 & 0.043 & 0.100 & -0.150 & $-0.18 \mathrm{I}$ & 0.090 & 0.123 & 0.032 & -0.105 \\
\hline 8. & 0.202 & -0.047 & 0.242 & 0.095 & 0.110 & 0.031 & -0.050 & -0.089 & -0.077 & 0.005 \\
\hline 9. & -0.027 & -0.100 & -0.386 & 0.076 & -0.035 & -0.007 & 0.113 & -0.130 & -0.134 & 0.252 \\
\hline $\mathrm{IO}$. & 0.064 & 0.215 & 0.344 & 0.124 & -0.001 & -0.025 & -0.074 & -0.137 & -0.124 & 0.014 \\
\hline II. & -0.189 & -0.149 & -0.146 & -0.144 & -0.062 & $-0.00 \mathrm{I}$ & -0.004 & -0.080 & -0.007 & -0.034 \\
\hline $\mathrm{I} 2$. & -0.196 & 0.040 & -0.087 & 0.155 & -0.105 & 0.016 & 0.077 & 0.203 & -0.059 & 0.033 \\
\hline $\mathrm{I3}$. & -0.181 & 0.014 & 0.231 & -0.098 & 0.108 & 0.026 & 0.002 & 0.124 & 0.073 & 0.095 \\
\hline I4. & -0.222 & -0.138 & -0.265 & -0.018 & 0.045 & $-0.04 \mathrm{I}$ & -0.119 & 0.053 & 0.003 & 0.045 \\
\hline 15. & 0.068 & 0.129 & 0.282 & -0.048 & -0.077 & $-0.2 \mathrm{II}$ & 0.070 & 0.002 & 0.004 & 0.020 \\
\hline
\end{tabular}

Note: Tested at $5 \%$ significance level.

Source: E-views output of the data sourced from IMD reports -I970 to 2019 
North Region

\section{Himachal Pradesh}
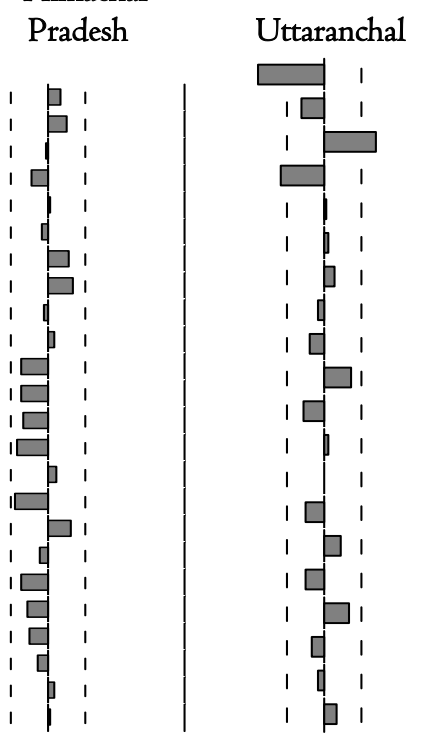

\section{East Region}

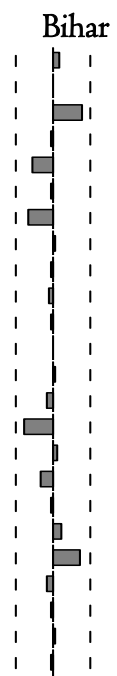

\section{Gangetic WB}

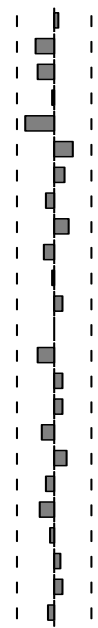

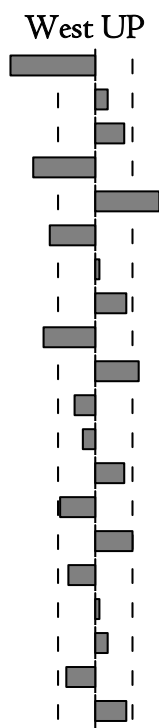

Odisha

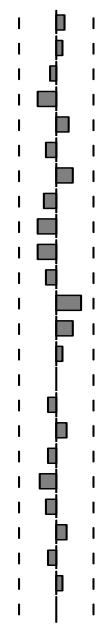

South Region

South

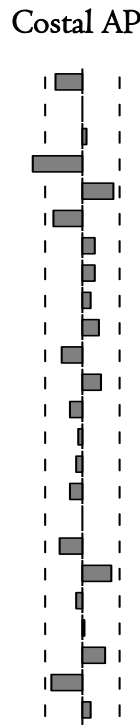

\section{West region}

\section{Gujarat}

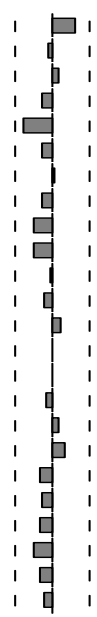
Interior $\mathrm{Kar}$

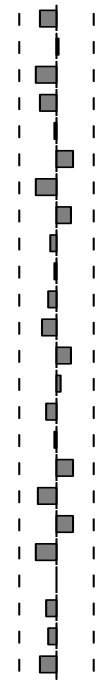

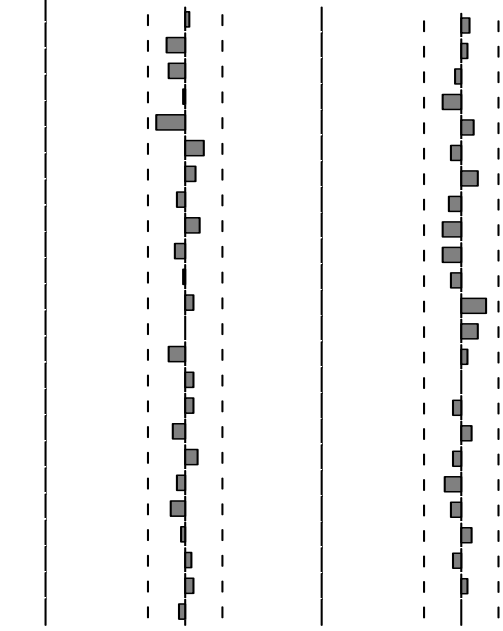

Saurashtra

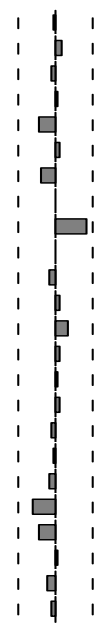

Figure 2. Autocorrelation Function (ACF) plot of ERD values Source: E-views output

The Autocorrelation Function (ACF) Figure 2 illustrates the correlation of the ERD series at various lags. The lag refers to the order of correlation. Each spike that rises above or falls below the dashed lines is considered to be statistically significant. This means the spike has a value that is significantly different from zero. If a spike is significantly different from zero, which is the evidence of autocorrelation. If a spike that is close to zero is the evidence of no autocorrelation in the series.

The ACF plots show that 7out of I0 sub-divisions are not statistically significant and within the $95 \%$ confidence interval. This indicating that there is no autocorrelation in the ERD values. The ERD values of these sub-divisions tend to fluctuate randomly around zero and they are independent of each lag. ACF plot of Uttaranchal, West UP, and Coastal Andhra Pradesh are statistically significant. This indicates that the ERD values have strong autocorrelation and they are dependent on each lag. 
Table 6.The results of the GARCH model

\begin{tabular}{|c|c|c|c|c|c|c|}
\hline Regions & Sub-divisions & $\alpha$ & $\beta$ & $\begin{array}{c}\operatorname{GARCH}(\mathrm{I}, \mathrm{I}) \\
(\boldsymbol{\alpha}+\boldsymbol{\beta})\end{array}$ & P-value & Volatility \\
\hline \multirow[t]{3}{*}{ North } & $\begin{array}{l}\text { HIMACHAL } \\
\text { PRADESH }\end{array}$ & -0.0769 & 0.7985 & 0.7216 & 0.0329 & High \\
\hline & UTTARANCHAL & 0.4522 & 0.3545 & 0.8067 & 0.1477 & High \\
\hline & WEST UP & 0.4330 & -0.0524 & 0.3806 & 0.9515 & Low \\
\hline \multirow[t]{2}{*}{ South } & $\begin{array}{l}\text { COSTAL ANDHRA } \\
\text { PRADESH }\end{array}$ & -0.3380 & 1.2847 & 0.9467 & 0.0000 & High \\
\hline & $\begin{array}{l}\text { SOUTH INTERIOR } \\
\text { KARNATAKA }\end{array}$ & -0.4369 & 1.3366 & 0.9066 & 0.0000 & High \\
\hline \multirow[t]{3}{*}{ East } & BIHAR & -0.3059 & I.3I35 & 1.0076 & 0.0005 & High \\
\hline & $\begin{array}{l}\text { GANGETIC WEST } \\
\text { BENGAL }\end{array}$ & $-0.367 \mathrm{I}$ & 1.3222 & $0.955 \mathrm{I}$ & 0.0000 & High \\
\hline & ODISHA & -0.3787 & 1.4042 & 1.0255 & 0.0000 & High \\
\hline \multirow[t]{2}{*}{ West } & GUJRAT REGION & -0.2425 & I.I7I7 & 0.9292 & 0.0000 & High \\
\hline & SAURASHTRA & -0.4583 & I.3265 & 0.8682 & 0.0000 & High \\
\hline
\end{tabular}

Source: E-views output of the data sourced from IMD reports - I970 to 2019

The results of GARCH models are reported in Table 6. GARCH model is used to test the volatility in the ERD series in selected MSDs of India. Table 6 represents two coefficients are $\alpha$ and $\beta$ indicating the estimated ARCH and GARCH coefficients. This coefficient is a measure of the persistence of volatility. The coefficient value is close to I(one) which indicates a high persistence of volatility in the ERD values. The results indicating that all IO subdivisions have high volatility expect West UP. It is observed that the sum of $\mathrm{ARCH}$ and GARCH coefficients $(\alpha+\beta)$ is very close to I(one) for all selected MSDs expect West UP sub-division as the computed p-value is lesser than the significance level alpha $=0.05$. Therefore, the study concludes that the selected subdivisions have high volatility persistence levels in the ERD values.

Table 7. Results of the Correlations matrix among selected MSDs.

\begin{tabular}{|c|c|c|c|c|c|c|c|c|c|c|}
\hline \multicolumn{11}{|c|}{ Spearman's tho Correlation Coefficient Sig. (2-tailed) } \\
\hline & $\begin{array}{c}\text { Gangetic } \\
\text { WB }\end{array}$ & Bihar & West UP & Uttaranchal & Odisha & $\begin{array}{l}\text { Gujarat } \\
\text { Region }\end{array}$ & Saurashtra & $\begin{array}{c}\text { Himachal } \\
\text { Pradesh }\end{array}$ & $\begin{array}{c}\text { Coastal } \\
\text { AP }\end{array}$ & $\begin{array}{c}\text { South } \\
\text { Interior } \\
\text { Kar }\end{array}$ \\
\hline \multirow{2}{*}{$\begin{array}{c}\text { Gangetic } \\
\text { WB }\end{array}$} & $\mathrm{I}$ & & & & & & & & & \\
\hline & & & & & & & & & & \\
\hline \multirow[t]{2}{*}{ Bihar } & $.313^{*}$ & $\mathrm{I}$ & & & & & & & & \\
\hline & $(0.027)$ & & & & & & & & & \\
\hline \multirow[t]{2}{*}{ West UP } & .029 & -.085 & $\mathrm{I}$ & & & & & & & \\
\hline & $(0.843)$ & $(0.557)$ & & & & & & & & \\
\hline \multirow{2}{*}{$\begin{array}{c}\text { Uttaranch } \\
\text { al }\end{array}$} & $.04 \mathrm{I}$ & -.074 & $.382^{*+*}$ & I & & & & & & \\
\hline & $(0.779)$ & $(0.610)$ & $(0.006)$ & & & & & & & \\
\hline \multirow[t]{2}{*}{ Odisha } & $-.03 \mathrm{I}$ & -.005 & $.08 \mathrm{I}$ & $.09 \mathrm{I}$ & $\mathrm{I}$ & & & & & \\
\hline & $(0.830)$ & $(0.975)$ & $(0.576)$ & $(0.52)$ & & & & & & \\
\hline \multirow{2}{*}{$\begin{array}{l}\text { Gujarat } \\
\text { Region }\end{array}$} & -.060 & -.064 & .270 & $.314^{*}$ & .180 & I & & & & \\
\hline & $(0.680)$ & $(0.658)$ & $(0.058)$ & $(0.026)$ & $(0.2 \mathrm{I})$ & & & & & \\
\hline \multirow[t]{2}{*}{ Saurashtra } & -.128 & -.164 & $.06 \mathrm{I}$ & $.290^{*}$ & .130 & $.565^{\ldots+}$ & $\mathrm{I}$ & & & \\
\hline & $(0.374)$ & $(0.254)$ & $(0.673)$ & $(0.04 \mathrm{I})$ & $(0.36)$ & $(0.00)$ & & & & \\
\hline \multirow{2}{*}{$\begin{array}{c}\text { Himachal } \\
\text { Pradesh }\end{array}$} & .091 & -.046 & $.488^{*}$ & .240 & .050 & .165 & .240 & $\mathrm{I}$ & & \\
\hline & $(0.528)$ & $(0.754)$ & $(0.000)$ & $(0.093)$ & $(0.73)$ & $\begin{array}{c}(0.25 \\
2)\end{array}$ & $(0.093)$ & & & \\
\hline \multirow{2}{*}{$\begin{array}{c}\text { Coastal } \\
\text { AP }\end{array}$} & -.024 & .140 &. $\mathrm{IIO}$ & .080 & -.126 & .139 & $.354^{*}$ & .197 & $\mathrm{I}$ & \\
\hline & $(0.868)$ & $(0.33 \mathrm{I})$ & $(0.447)$ & $(0.580)$ & $(0.38)$ & $\begin{array}{c}(0.33 \\
7)\end{array}$ & $(0.012)$ & $(0.170)$ & & \\
\hline South & -.093 & .045 & .039 & $-.05 \mathrm{I}$ & .230 & $.04 \mathrm{I}$ & $.293^{*}$ & -.104 & $.304^{*}$ & I \\
\hline
\end{tabular}




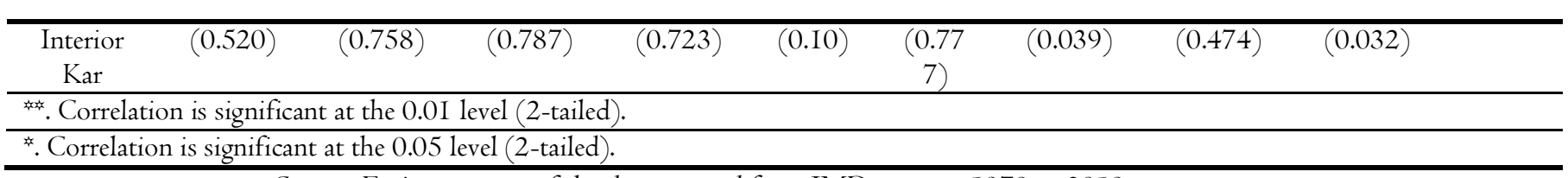

Source: E-views output of the data sourced from IMD reports - I970 to 2019

Table 7 depicts the degree of inter-sub division dependency in ERD values of rainfall data. The pair-wise correlation analysis amongst ten selected sub-divisions has been carried out. It is found that the correlation value range between a maximum of +0.565 and a minimum of -0.164 . The result shows that out of 45 pair-wise interrelationships, 3 I out of 45 pairs have a very weak positive correlation. The remaining I4 pairs have a negative correlation. It is observed that ERD values among the sub-divisions have a weak correlation.

The majority of the inter-sub divisions have a weak (i.e., near to zero and negative) correlation with 5\% and $10 \%$ significance value. Hence, Excess Rainfall Days (ERDs) indices across inter-Meteorological Sub-divisions are significantly uncorrelated. ERDs can be used as a distinct asset class. Stakeholder like agri-insurance companies, having sold rainfallbased index insurance policies across a wide geographical area, can minimize their exposure by building a diversified portfolio of ERD indices. Hence, there exists a vast scope for trading ERD index-based financial derivatives for hedging across MSDs.

\section{Scope for Designing Rainfall Derivatives}

The increasing popularity of temperature-based weather derivatives in the U.S. and Europe has brightened the prospects of innovating with rainfall based weather derivatives, particularly in some agro-based developing economies. The Indian situation with monsoon is the perfect opportunity to design derivative products. The monsoon has an enormous impact on many enterprises, including agriculture, commodity trading, agro-processing, energy, and insurance. The stakeholders in these markets have the need to manage monsoon related risks through rainfall derivatives. From a boarder perspective, risk markets have the potential to yield additional benefits too. They can promote the integration of markets by expanding the horizon of asset classes for investment. From the perspective of Markowitz's mean-variance efficiency, as long as the market is not complete, a new asset class will always improve the risk-return trade-off (Cao \& Wei, 2004). ERDs could be used as building blocks for designing rainfall derivatives similar to HDDs/CDDs underlying temperature derivatives. Several of the statistical properties of ERD indices fully support this idea. The risk underlying seasonal rainfall is indicated by the degree of volatility in ERD indices. The results of GARCH models have shown that all the $\mathrm{IO}$ sub-divisions have volatility except West UP. Another interesting property of ERD indices is that indices across inter MSDs are significantly uncorrelated. This is particularly useful when ERDs are used as a distinct asset class, by building a diversified portfolio by such stakeholders like general insurance companies having sold rainfall-based index insurance policies across a wide geographical area.

\section{Conclusion}

India faces most of the losses from an increase in flood events and cyclones, which are projected to increase in magnitude and frequency in the near future. Hence, India has high exposure to weather-related events. In this background, the study aims to develop the framework of standard indexation that could serve as a basis for designing rainfall-index based insurance and derivatives contracts. Flood index, i.e., Excess Rainfall days (ERDs) index has been developed to measure the flood risk with special reference to South-West monsoon. The research is based on the applications of econometric models such as the Augmented Dickey-Fuller (ADF) test followed by the GARCH model. Several of the statistical properties of ERD indices support the idea that these indices could be used as building blocks for designing rainfall derivatives similar to HDDs/CDDs underlying temperature derivatives.

\section{Research Implications}

Research has a major implication for policymaking in the field of rainfall risk management. The research inputs of the study, to help the creation of the market for trading rainfall derivatives like futures and options that could be used by stakeholders for minimizing the exposure monsoon adverse events. The SEBI has initiated a discussion on proposing new standardized weather derivative products that can be used to minimize the weather-related risk in India. So, the study would provide some inputs to develop standard metrics for measuring excess rainfall as ERDs. This rainfall indexation would serve as a benchmark for designing rainfall options and futures contracts for trading both in over-the-counter and organized markets.

\section{I0. Limitations of the Study}

The study is based upon monthly rainfall data collected from Indian Meteorological Department (IMD). Instead, if the rainfall data is collected on daily basis results could be more accurate. 


\section{Scope for Further Research}

The present study was analyzed on the statistical properties of Excess Rainy Days (ERDs) for only I0 out of 36 Meteorological Subdivisions. Further study can also be taken to consider the statistical properties of Excess Rainy Days (ERDs) of all 36 Meteorological Sub-division.

\section{Acknowledgment}

The authors thank the Indian Meteorological Department (IMD) for providing cost-free rainfall data for this study. The authors received financial support from ICSSR, New Delhi for the research, authorship, for the publication of this article.

\section{References}

Anastasiadou, Z., \& López-Cabrera, B. (2013). On the modeling of temperature dynamics for pricing weather-related products. Journal of Energy Markets, 6(4), 3-24. https://doi.org/I0.2I3I4/JEM.2013.098

Bollerslev, T. (1986). Generalized autoregressive conditional heteroskedasticity. Journal of econometrics, 3I(3), 307327.https://doi.org/I0.1016/0304-4076(86)90063-I

Campbell, S. D., \& Diebold, F. X. (2005).Weather forecasting for weather derivatives. Journal of the American Statistical Association, IOO(469), 6-I6. https://doi.org/I0.I 198/0I62I450400000I05I

Chacko, K., Ranadive, R., Sachdeva, M., Hede, S., Bhati, S. B. B., Nainan, A., \& Jagasheth, U. (2018). Economic and Industrial impact of Kerala Floods" Care ratings. Retrieved from http://www.careratings.com/upload/NewsFiles/SplAnalysis/Economic\%20and\%20Industrial\%20Impact\%2 OKerala.pdf

Cao, M., \& Wei, J. (2004). Weather derivatives valuation and market price of weather risk. Journal of Futures Markets: Futures, Options, and Other Derivative Products, 24(I I), I065-I089. https://doi.org/ I0.1002/fut.20122

Dickey, D. A., \& Fuller, W. A. (I979). Distribution of the estimators for autoregressive time series with a unit root. Journal of the American statistical association, 74(366a), 427-43I.https://doi.org/I0.I080/ 0I62I459.1979.I048253I

Dickey, D. A., \& Fuller, W. A. (I98I). Likelihood ratio statistics for autoregressive time series with a unit root. Econometrica: Joumal of the Econometric Society, I057-I072.https://doi.org/0012-9682(198107)49: 4<I057:LRSFAT>2.0.CO;2-4

Government of India, Central Water Commission. (2019). Water and Related Statistics report 2019. Retrieved from http://www.cwc.gov.in/publications.

IPCC, W. (1995).Climate Change I995-The science of climate change. Contribution of Working Group I to the Second Assessment Report of the Intergovernmental Panel on Climate Change. JT Houghton et al. Retrieved from https://www.ipcc.ch/site/assets/uploads/2018/06/2nd-assessment-en.pdf

Kotreshwar, G. (2006). Managing monsoon risk in India, why not Monsoon Derivatives?. The ICFAI journal of derivatives markets, 3(3), 76-83.

Kotreshwar, G., \& Kanakasabai, M. (2006). Design and pricing of Monsoon Derivatives: A conceptual frame work. In $A$ paper presented at international conference of Asia Pacific Risk \& Insurance Association (APRIA).

Kotreshwar, G., \& Arunkumar, R. (2006). Monsoon Risk Securitisation: Monsoon Options on Select Met Subdivisions.IOth Capital Markets Conference, Indian Institute of Capital Markets Paper:http://dx.doi.org/I0.2139/ssrn.962322

Kotreshwar, G., (2015). Securitisation of Rainfall Risk in India: Designing Rainfall Derivative Contracts Based on Standard Metrics. Paper presented in International Conference on Emerging Trends in Finance Accounting, SDM-IMD, Mysuru.

Kumar, K. K., \& Parikh, J. (200I). Indian agriculture and climate sensitivity. Global envitonmental change, II(2), I47I54. http://dx.doi.org/I0.I0I6/S0959-3780(0I)00004-8

Mooley, D. A., \& Parthasarathy, B. (1983). Indian summer monsoon and El Nino. Pure and Applied Geophysics, I2 I(2), 339-352.https://doi.org/I0.1007/BF02590I43

Mooley, D. A., Parthasarathy, B., Sontakke, N. A., \& Munot, A. A. (I98I). Annual rain-water over India, its variability and impact on the economy.Journal of Climatology, I(2), I67-I86.https://doi.org/ I0.I002/joc.33700I0206

Parthasarathy, B., Munot, A. A., \& Kothawale, D. R. (I994). All-India monthly and seasonal rainfall series: I87I1993. Theoretical and Applied Climatology, 49(4), 217-224. https://doi.org/I0.I007/BF0086746I

Shivkumar, D., \& Kotrshwar, G. (2013).Trading in weather risk transfer products-Reengineering rainfall indexation. International Journal of Business and Management Invention, 2(II), 33-4I.Retrieved from https://www.ijitee.org/download/volume-8-issue-5/

Stoppa, A., \& Hess, U. (2003, June). Design and use of weather derivatives in agricultural policies: the case of rainfall index insurance in Morocco. In International Conference "Agricultural Policy Reform and the WTO: Where are we heading”, Capri (Italy).Retrieved from https://pdfs.semanticscholar.org/c35b/55afd4a2If 2ee7d2ecdf5460cca5cbe35I4.pdf

Singh, C., Del Rio, C. R., Soundarajan, V., Nath, V. \& Shivaranjani, V. (20I8). Assessing India's mounting climate losses to Financial Institutions" Action on Climate today. Retrieved from http://www.indiaenvironmentportal.org.in/files/file/climate-losses-revised.pdf 
Appendix- A

ERD values for South-west monsoon for 50 years (I970-2019)

(For Selected Meteorological Sub-Divisions (MSDs) of India)

\begin{tabular}{|c|c|c|c|c|c|c|c|c|c|c|}
\hline \multirow[b]{2}{*}{ Years } & \multicolumn{3}{|c|}{ North } & \multicolumn{2}{|c|}{ South } & \multicolumn{3}{|c|}{ East } & \multicolumn{2}{|c|}{ West } \\
\hline & $\begin{array}{c}\text { Himachal } \\
\text { Pradesh }\end{array}$ & Uttarachal & West UP & $\begin{array}{l}\text { Costal } \\
\text { AP }\end{array}$ & SIK & Bihar & $\begin{array}{c}\text { Gangetic } \\
\text { WB }\end{array}$ & Odisha & Gujrt & Saushtra \\
\hline 1970. & $\mathrm{I} 49 . \mathrm{I} 4$ & 44 & I6I.92 & 9I.II & 13.2 & 45.07 & 271.01 & 98 & 523.95 & 304.12 \\
\hline I97I. & 320.54 & I7I & I5I.38 & 20.26 & 55.44 & 212.46 & 386.95 & 136 & 45.63 & 55.49 \\
\hline I972. & 0 & 28 & 0 & 7.55 & $25.3 \mathrm{I}$ & 0 & 222.86 & $7 \mathrm{I}$ & 0 & 0 \\
\hline I973.I & 0 & 103 & 87.73 & 4.76 & 99.76 & 93.27 & I44.55 & 152 & 337 & 0 \\
\hline I974. & 0 & 24 & II8.26 & 44.56 & I48.04 & 175 & 92.67 & 0 & 0 & 0 \\
\hline 1975. & 0 & 250 & 251.38 & 87.39 & 239.57 & 95.64 & 44.42 & 94 & 353.85 & I50.46 \\
\hline 1976. & I24.47 & 0 & I4.67 & 100.94 & 0 & 178.73 & 0 & 29 & 663.52 & 95.26 \\
\hline 1977. & I75.24 & I42 & 245.66 & 0 & 31.47 & 38.87 & 270.45 & 39 & $4 \mathrm{I} 7.32$ & 86.19 \\
\hline 1978. & I70.6I & 503 & 443.88 & III.55 & 136.07 & 59.97 & 348.85 & 105 & I53.13 & $75.0 \mathrm{I}$ \\
\hline 1979. & 0 & 0 & 2.46 & 37.36 & II9.44 & 98.87 & 29.82 & 0 & I53.7I & $538.3 \mathrm{I}$ \\
\hline I980. & 239.48 & II8 & 268.98 & $78.6 \mathrm{I}$ & I52.27 & I58.03 & I07.89 & $2 \mathrm{I} 4$ & $\mathrm{I} 25.73$ & 283.64 \\
\hline I98I. & 0 & $\mathrm{I} 27$ & 97.21 & I06.34 & 207.21 & 284.23 & I47.55 & 20 & 178.96 & I08.37 \\
\hline 1982. & 0 & 83 & I72.87 & 0 & 46.83 & 59.5 & 0 & I09 & 0 & 0 \\
\hline 1983. & 4.37 & 136 & 310.58 & 222.05 & 160.44 & 21.64 & 45.06 & 109 & 249.15 & 240.96 \\
\hline I984. & 9.38 & I48 & 89.42 & $3 \mathrm{I} .38$ & 96.07 & 339.34 & 465.88 & I93 & I35.2I & 30.35 \\
\hline 1985. & 68.7 & 163 & I4I.56 & 5.18 & 33.73 & 218.04 & 47.58 & 201 & 0 & 0 \\
\hline 1986. & 5.16 & 49 & I4.15 & 72.56 & 90.54 & 69.54 & 250.49 & 96 & 48.63 & 78.09 \\
\hline 1987. & 0 & 0 & 0 & 0 & 0 & 553.7 & 234.23 & 3 & 0 & 0 \\
\hline I988. & 472.9 & 178 & 270.48 & 272.8 & I6I.94 & 228.33 & 255.72 & 55 & 299.54 & 370.9 \\
\hline 1989. & 52.23 & 38 & 27.95 & I88.3 & 68.83 & 224.14 & I46.28 & I37 & 43.66 & II8.94 \\
\hline 1990. & 103.54 & I62 & 214.06 & 10.52 & 0.1 & I48.87 & 216.88 & 66 & 329.6 & 100.72 \\
\hline I99I. & 27.93 & 0 & I89.07 & I84.0I & I36.I6 & I2I.33 & 47.85 & 204 & I24.I5 & 0 \\
\hline 1992. & 175.8 & 35 & I2I.47 & 26.24 & $\mathrm{I} 34.33$ & 0 & 59.07 & 82 & 101.29 & I58.45 \\
\hline 1993. & I68.44 & 263 & I94.I5 & 0 & 0 & I90.63 & 267.37 & IOO & 248.64 & 0 \\
\hline 1994. & 206.04 & 185 & I83.43 & 26.78 & I44.96 & 10.37 & 139.29 & 483 & 578.02 & 381.49 \\
\hline 1995. & 358.7 & I79 & I59.87 & I00.64 & 32.43 & 128.13 & 303.62 & 9 & II3.35 & 70.35 \\
\hline 1996. & 201.64 & 0 & I60.72 & I52.25 & 82.84 & 138.46 & 301.38 & 23 & 50.84 & 56.39 \\
\hline 1997. & 234.36 & 0 & 0 & 136.86 & I07.56 & 192.43 & I6I.83 & 123 & 293.63 & I83.74 \\
\hline I998. & I86.68 & 0 & I45.33 & I50.9 & 96.44 & 235.33 & 23.79 & 40 & 204.49 & 22.79 \\
\hline 1999. & I07.24 & 0 & $\mathrm{I} 29.4$ & 0 & 73.33 & 223.33 & 327.34 & 44 & 21.73 & 0 \\
\hline 2000. & II8.68 & 198 & 83.48 & $2 \mathrm{I} 8.4 \mathrm{I}$ & I48.34 & 202.97 & I60.39 & $2 \mathrm{I}$ & 0 & 46.95 \\
\hline 2001. & $\mathrm{I} 45.84$ & 205 & I32.6I & $23.1 \mathrm{I}$ & 43.01 & 171.97 & II5.62 & 445 & I78.8 & 79.04 \\
\hline 2002. & I52.93 & 255 & 160.87 & $10.7 \mathrm{I}$ & 0 & 68.97 & II5.II & 0 & 133.93 & I29.69 \\
\hline 2003. & 269 & 373 & 358.96 & 89.48 & 0 & 176.53 & I4.92 & II8 & 362.4 & 248.66 \\
\hline 2004. & 0 & 333 & $\mathrm{I} .77$ & 20.69 & 5.33 & 159.77 & 55.56 & 6 & $262.5 \mathrm{I}$ & $85.9 \mathrm{I}$ \\
\hline 2005. & I58.84 & 376 & I65.06 & I46.24 & I36.63 & 66.16 & 0 & 201 & 528.12 & 253.14 \\
\hline 2006. & 0 & 48 & 6.46 & 53.57 & II.I3 & 81.67 & 220.36 & 462 & 580.46 & 216.07 \\
\hline 2007. & 0 & 509 & 6.35 & 213.97 & I98.47 & 390.1 & 444.22 & 346 & 315.85 & $36 \mathrm{I} .5 \mathrm{I}$ \\
\hline 2008. & I09.48 & $\mathrm{I} 22$ & I74.4I & 78.94 & 65 & 236.43 & 173.92 & 296 & I64.3 & I37.75 \\
\hline 2009. & 69.87 & $\mathrm{I} 2$ & 0 & 0 & 204.14 & 48.56 & 31.25 & 275 & 78.65 & 241.85 \\
\hline 2010. & I7I.8I & 673 & I57.53 & 256.25 & 45.34 & 0 & 0 & 0 & 200.95 & 495.42 \\
\hline 2011. & I2I.37 & $4 \mathrm{II}$ & 86.65 & 49.74 & 6.23 & I50.23 & 320.57 & $\mathrm{I} 22$ & 188.2 & 257.52 \\
\hline 2012. & I04.83 & I7I & 2.37 & 99.7 & 20.6 & 6.57 & 0 & 64 & I08.29 & 133.65 \\
\hline 2013. & $\mathrm{I} 44.87$ & 390 & 158.22 & 7.18 & I 48.57 & 20.4 & 78.46 & 108 & 335.82 & 309.49 \\
\hline 2014. & 0 & 94 & 0 & 0 & I26.34 & 37.06 & 0 & 233 & I 47.94 & 28.95 \\
\hline 2015. & 16.17 & 35 & 0 & II 8.47 & 60.64 & $\mathrm{I} 2.45$ & 276.17 & 30 & 50 & 121.19 \\
\hline 2016. & 32.27 & I62 & II4.I6 & I49.6I & I3.33 & I6I.54 & 96.36 & 29 & I7.2I & 55.72 \\
\hline
\end{tabular}




\begin{tabular}{ccccccccccc}
\hline 2017. & 54.47 & I 45 & II.65 & I05.49 & $98.6 \mathrm{I}$ & II0.86 & I43.47 & I5 & 284.62 & I 80.25 \\
\hline 2018. & 227.94 & I4I & I36.93 & 70.89 & 29.03 & 0 & 0 & 204 & I3.95 & 30.85 \\
\hline 2019. & 82.46 & 53 & 0 & 99.3 & 224.61 & 258.44 & 34.05 & I92 & I79.I & II73.47 \\
\hline
\end{tabular}

\section{Copyrights}

Copyright for this article is retained by the author(s), with first publication rights granted to the journal. This is an openaccess article distributed under the terms and conditions of the Creative Commons Attribution license (http://creativecommons.org/licenses/by/4.0/). 